\title{
Corrigendum: CD1d-Invariant Natural Killer T Cell-Based Cancer Immunotherapy: $\alpha$-Galactosylceramide and Beyond
}

\author{
Lisa A. King ${ }^{1}$, Roeland Lameris ${ }^{1}$, Tanja D. de Gruijl ${ }^{1}$ and Hans J. van der Vliet ${ }^{1,2 *}$ \\ 1 Department of Medical Oncology, VU University Medical Center and Cancer Center Amsterdam, Amsterdam, Netherlands, \\ ${ }^{2}$ Lava Therapeutics, Den Bosch, Netherlands
}

Keywords: iNKT cells, CD1d, $\alpha$-GalCer, glycolipids, cancer immunotherapy

\section{A Corrigendum on}

CD1d-Invariant Natural Killer T Cell-Based Cancer Immunotherapy: $\alpha$-Galactosylceramide and Beyond

OPEN ACCESS

Approved by:

Frontiers in Immunology Editorial

Office,

Frontiers Media SA, Switzerland

*Correspondence:

Hans J. van der Vliet

jj.vandervliet@vumc.nl

Specialty section: This article was submitted to

T Cell Biology,

a section of the journal

Frontiers in Immunology

Received: 19 October 2018

Accepted: 23 October 2018

Published: 20 November 2018

Citation:

King LA, Lameris R, de Gruijl TD and van der Vliet HJ (2018) Corrigendum:

CD1d-Invariant Natural Killer T Cell-Based Cancer Immunotherapy: $\alpha$-Galactosylceramide and Beyond.

Front. Immunol. 9:2606.

doi: 10.3389/fimmu.2018.02606 by King, L. A., Lameris, R., de Gruijl, T. D., and van der Vliet, H. J. (2018). Front. Immunol. 9:1519. doi: 10.3389/fimmu.2018.01519

In the original article, we neglected to disclose that authors Lisa A. King and Roeland Lameris are currently funded by Lava Therapeutics and that Hans J. van der Vliet also acts as chief scientific officer of Lava Therapeutics. Hans J. van der Vliet's affiliation has been updated to reflect this. The corrected Conflict of Interest statement appears below.

\section{CONFLICT OF INTEREST STATEMENT}

LK and $\mathrm{Rl}$ are funded by Lava Therapeutics. HV acts as chief scientific officer of Lava Therapeutics. The remaining author declares that the research was conducted in the absence of any commercial or financial relationships that could be construed as a potential conflict of interest.

The authors apologize for this error and state that this does not change the scientific conclusions of the article in any way. The original article has been updated.

Conflict of Interest Statement: LK and Rl are funded by Lava Therapeutics. HV acts as chief scientific officer of Lava Therapeutics.

The remaining author declares that the research was conducted in the absence of any commercial or financial relationships that could be construed as a potential conflict of interest.

Copyright (c) 2018 King, Lameris, de Gruijl and van der Vliet. This is an open-access article distributed under the terms of the Creative Commons Attribution License (CC BY). The use, distribution or reproduction in other forums is permitted, provided the original author(s) and the copyright owner(s) are credited and that the original publication in this journal is cited, in accordance with accepted academic practice. No use, distribution or reproduction is permitted which does not comply with these terms. 